\title{
Daily Fluctuations in Office-Based Workers' Leisure Activities and Well-Being
}

\author{
Julie Ménard ${ }^{1}$, Annie Foucreault ${ }^{1}$, Célestine Stevens ${ }^{1}$, Sarah-Geneviève Trépanier ${ }^{1} \&$ Paul Flaxman $^{2}$ \\ ${ }^{1}$ Department of Psychology, Université du Québec à Montréal, Montréal, Québec, Canada \\ ${ }^{2}$ Department of Psychology, City, University of London, Northampton Square, London \\ Correspondance: Julie Ménard, Department of Psychology, Université du Québec à Montréal, C. P. 8888, Succ. \\ Centre-Ville, Montréal, Québec, H3C 3P8, Canada. E-mail: menard.julie@uqam.ca
}

Received: October 28, 2016

Accepted: November 28, 2016

Online Published: December 22, 2016

doi:10.5539/ijps.v9n1p47

URL: http://dx.doi.org/10.5539/ijps.v9n1p47

\begin{abstract}
This day-level study examines links between the amount of leisure time devoted to social, physical, and low-effort activities after the workday and affective well-being at bedtime. A sample of 95 office-based workers completed surveys over four consecutive days at bedtime (380 data points). Results revealed a within-person effect of leisure activity on daily affective well-being. Participants consistently reported enhanced mood before sleep on days when they spent more hours engaging in physical and social activities compared to their personal average number of hours spent on these activities across the four days of the study. However, on days when more hours were spent on low-effort activity, participants consistently reported decreased positive emotions. This suggests that time allocation to certain leisure activities may better support well-being on a daily basis. Discussion focuses on the implications of these findings for helping individuals enhance their evening leisure experiences by making astute leisure choices.
\end{abstract}

Keywords: leisure, affective well-being, daily mood, office-based staff, daytime workers

\section{Introduction}

Previous research suggests that leisure significantly contributes to well-being (Doerksen, Elavsky, Rebar, \& Conroy, 2014; Newman, Tay, \& Diener, 2014). Recent workplace changes such as increased use of Information and Communication Technology (ICT) and organizational downsizing have led workers to experience a faster-paced job and to feel the need to be more available to meet their employer's demands (Chesley, 2014; de Jong et al., 2016). Periods that were traditionally devoted to leisure such as evenings, work breaks, weekends, and vacations, are now also used for work-related activities, which is detrimental for workers' well-being (Chesley, 2014; de Jong et al., 2016). Leisure activities offer many opportunities to recover and to replenish personal resources (e.g., energy, concentration) spent to fulfill life role demands (e.g., working, childcare). The nature and function of leisure activities and experiences among the working population have increasingly been the focus of research (e.g., Celen-Demirtas, Konstam, \& Tomek, 2015; Cropley, Dijk, \& Stanley, 2006; Eden, 2001; Schüz et al., 2015; Sonnentag, 2001; Sonnentag \& Fritz, 2007).

It is well-established from between-person studies (i.e., differences between those who participate to a certain type of leisure activity and those who do not) that leisure is an efficient way to promote well-being (Lin, Huang, Yang, \& Chiang, 2014; Newman, Tay, \& Diener, 2014). Leisure participation has the potential to help workers to build new personal resources such as positive emotions, skills, knowledge and social relationships, and thereby to enhance their overall quality of life and well-being (Brajša-Žganec, Merkaš, \& Šverko, 2011). Over the past years, a growing set of studies has shown the benefits of leisure on workers' daily well-being (e.g., Sonnentag, Binnewies, \& Mojza, 2008; Sonnentag \& Zjilstra, 2006; Sonnentag, 2001).

This study aims to reinforce conclusions from previous studies on the positive relationship between leisure and workers' daily mood in a sample of office-based staff from the UK. Office-based staff is typically composed of daytime workers with fixed schedules. This population of workers has both a similar and predictable schedule and time to devote to leisure. Daily leisure participation amongst this population is mostly during the evening. The research participants recorded time spent on leisure activities across four consecutive evenings and rated their momentary affective well-being just before sleep. This research design was used to obtain the specific benefits of 
various types of evening leisure activities (i.e., physical, social, and low-effort) on four types of daily moods in order to help office-based workers make astute decisions on the types of evening leisure activities they may wish to engage in. Office-based staff represents a large proportion of the international (International Labour Organization, 2008) and in the UK workforce (Office for National Statistics, 2016). Results and recommendations regarding use of leisure time as an opportunity to increase affective well-being thus concern a significant number of workers.

The following section focuses on why leisure on a daily basis may be important to well-being.

\section{Theoretical Perspective on Workers' Well-Being and Leisure}

\subsection{Well-Being and Leisure}

Well-being is defined as a global and subjective judgment about the level of positive and negative emotions that are experienced by an individual (Wright \& Hobföll, 2004). Daily leisure could be an efficient way to promote workers' well-being with intrinsically rewarding experiences (Iso-Ahola, 1980). Stebbins (2005) defined leisure as an "uncoerced activity undertaken during free time where such activity is something people want to do and, at a personally satisfying level using their abilities and resources, they succeed in doing (p. 350)". It is the time when people have the most control over activity participation (Shaw, 1985). Leisure is recognized as an opportunity to gain personal resources, thus helping workers maintain well-being (Kinnunen et al., 2016; Korpela \& Kinnunen, 2011; Sonnentag, 2001). Personal resources are necessary to well-being because they offer resilience to stress and are linked to one's perceived ability to control and have an impact on one's environment (Hobföll, 1989, 2002). During the workweek, office-based staff normally devotes more time to work than to leisure. It therefore seems that leisure time used wisely could promote staff's daily well-being through personal resources gains.

Physical, social and low-effort activities are the most common activities that can be performed daily after the workday (Sonnentag, 2001). In a study concerning daily off-job activities, Sonnentag (2001) created three categories of activities that can be performed in the evening, namely: (1) job-related, (2) household and child-care activities, and (3) leisure activities. The latter comprises physical, social and low-effort activities. In the following section, each of these leisure activities will be defined and current knowledge of its potential to promote well-being will be presented.

\subsection{Leisure Activities}

\subsubsection{Physical Activity}

Physical activity is defined as any bodily movement produced by skeletal muscles that requires energy expenditure (Caspersen, Powell, \& Christenson, 1985). It includes gentle exercise, as well as physical training and sports. A compelling body of research has shown the link between physical activity (including structured and unstructured exercise) and various indicators of psychological health and well-being (e.g., Bucksch \& Schlicht, 2006; Bültmann et al., 2002; Raglin, Wilson, \& Galper, 2007; Reed \& Ones, 2006). According to Rook and Zijlstra (2006) physical activity calls upon different resources than those typically used by office-based staff (cognitive and emotional resources), thus allowing the latter resources to be replenished because such physical resources are not over-used during leisure periods (see Hobföll's, 1989; Conservation of Resources Model). Not draining further cognitive or emotional resources could explain why physical activity has been associated with well-being, decreased fatigue and improved mood in correlational (e.g., Coffeng, van Sluijs, Hendriksen, van Mechelen, \& Boot, 2015) and prospective studies (e.g., Bültmann et al., 2002). Thus, physical activity is often viewed as a means to decrease stress, and promote well-being (Iwasaki, 2001; McMahon et al., 2016).

A lot of what is known about the benefits of physical activity comes from clinical populations (e.g., Wipfli, Rethorst, \& Landers, 2008), and not from workers, although some (i.e., Hyde, Conroy, Pincus, \& Ram, 2011; Sonnentag, 2001) have shown its benefits at the day-level. Results from previous studies on the daily psychological outcomes from unstructured daily physical activity (e.g., going for a walk) need to be reproduced in various samples of workers to strengthen the validity of conclusions from previous studies. Thus, this study aims to determine if daily variation (i.e., considering one's personal average) of time spent on physical activity after work is associated with change in affective well-being amongst a sample of office-based staff. Based on the available evidence, it was hypothesized that:

Hypothesis 1: Devoting more time than the personal average to physical activity is related to an augmentation of daily psychological well-being. Participants will report (a) more positive emotions, (b) less negative emotions, (c) less anxiety, and (d) less fatigue before sleep on days when more time than their own personal average is spent on physical activity after the workday. 


\subsubsection{Social Activity}

Social activity is a distinct category of leisure activity that focuses on social contacts between the individual and family members, friends or other members of his or her social network (Sonnentag, 2001). Social activity has the potential to enhance a sense of relatedness, a basic psychological need for feeling close and connected to significant others (Brannan, Biswas-Diener, Mohr, Mortazavi, \& Stein, 2013; Deci \& Ryan, 2000). It is perceived by most as a mood enhancer (Clark \& Watson, 1988) but even if studies usually abound in this direction, results have been mixed. While most have shown that engaging in social leisure activity was positively related to well-being (e.g., Chang, Wray, \& Lin, 2015; Fritz \& Sonnentag, 2005), others have also shown that it was negatively related to well-being since it has been associated to poor recovery from work demands (Sonnentag \& Zijlstra, 2006), fatigue (Rook \& Zijlstra, 2006; Sonnentag \& Bayer, 2005) and depressive symptoms (Sonnentag \& Natter, 2004). Considering that this study is on office-based staff, social activity should promote well-being because it might be an efficient source of social support. According to the triple-match principle (TMP, de Jonge \& Dormann, 2006), resources gained are most likely to be beneficial if the nature of these resources match the stressors workers are confronted with. Office-based workers spend a considerable amount of their resources meeting social demands at work (e.g., answer inquiries from clients, provide support to colleagues). Consequently, employees should benefit from social resources gained through social activity. Additionally, Greenhaus and Powell's (2006) theory of work-family enrichment states that social capital (i.e., the goodwill that is derived from the formation of social relationships and which can be mobilized to facilitate action) created in one role can be used to improve performance and well-being of the individuals in another role. For example, workers may use the tips and recommendations from friends and relatives (i.e., resources) gained from participation in social activity to solve problems at work, thereby reducing their stress level and improving their well-being (Greenhaus \& Powell, 2006). Thus, it was hypothesized that:

Hypothesis 2: Devoting more time than the personal average to social activity is related to an augmentation of daily psychological well-being. Participants will report (a) more positive emotions, (b) less negative emotions, (c) less anxiety, and (d) less fatigue before sleep on days when more time than their own personal average is spent on social activity after the workday.

\subsubsection{Low-Effort Activity}

Low-effort activity includes watching television, reading, relaxing on the sofa, or taking a bath (Sonnentag, 2001). It was defined in this study as any sedentary behavior (Sedentary Behaviour Research Network, 2012) that excludes social contacts. Surveys conducted in the U.S. suggest that citizens over the age of 15 spend an average of 2.5 hours per day watching television on weekdays, making this the most common weekday leisure activity (Bureau of Labor Statistics, 2016; Nielsen Media Research, 2009). A four-day study of 30 families confirms the trend, as television viewing was the second most frequently performed activity at home (Saxbe, Graesch, \& Alvik, 2011). Low effort activity requires very low energy expenditure on the part of individuals, thus placing no pressure on their psychobiological system (Demerouti, Bakker, Geurts, \& Taris, 2009). As low-effort leisure activity requires use of very few resources, and may instead facilitate relaxation and reduce fatigue following a demanding or stressful work situation (Karasek \& Theorell, 1990; Sonnentag, 2001), it was hypothesized that:

Hypothesis 3: Devoting time to low-effort activity after the workday is related to an augmentation of daily psychological well-being. Participants will report (a) more positive emotions, (b) less negative emotions, (c) less anxiety, and (d) less fatigue before sleep on days when more time than their own personal average was spent on low-effort activity after the workday.

\section{Method}

\subsection{Sampling}

The data were obtained from a convenience sample. Two sampling methods were used in order to recruit office-based staff working in the public and private sectors in the United Kingdom. First, an electronic invitation was sent to the university staff. A total of 56 office-based workers from that university volunteered for the diary study and received the questionnaires through their personal email address. Second, in order to increase the sample size, graduate students of the Organizational Psychology program were encouraged to send the invitation to office-based workers from their personal network, resulting in a total sample size of 95 participants. According to Ohly et al. (2010), a sample size of more than 30 participants is adequate in diary studies. Based on the Industry Classification Benchmark (ICB, 2010), the 39 participants recruited from graduate students represented a variety of industries: finance (11.6\%), industrial (5.3\%), consumer goods $(6.3 \%)$, consumer services $(12.6 \%)$, healthcare (2.1\%), and oil and gas (1.1\%). Inclusion criteria were the following: (a) 18 years of age and older, (b) working over the four consecutive days of the study, and (c) returning the initial questionnaire and daily surveys completed 
for the working week. Most participants (64\%) were female, worked full-time (87\%), and the average age was 34.5 $(S D=11.4)$. The majority of participants $(75 \%)$ had no children and $47 \%$ were married or had a partner. Participants worked for an average of $37.9(S D=7.97)$ hours during the week of survey completion. Average tenure with their current institution was 4.9 years $(S D=5.9)$. Based on job titles reported by participants, a dummy variable was created in order to identify their job status $(1=$ employee, $2=$ manager $)$. A total of $68.4 \%$ were employees and $26.3 \%$ had managerial functions.

\subsection{Data Collection}

The project was approved by the University Research Ethics Committees of our institution. A survey package containing a consent form, an initial questionnaire, a diary and a prepaid return envelope was mailed to each participant. In the consent form, participants were assured of confidentiality and a reference number was used in each survey booklet. Participants were asked to complete an evening diary over four consecutive weekdays (from Monday to Thursday). Almost all diaries were completed across the four days of the study (Monday $=94$, Tuesday $=93$, Wednesday $=92$, and Thursday $=92$ diaries). Sunday and Friday evenings were excluded because they were considered weekend days (i.e., not representative of typical weekdays since workers could have more time for leisure).

In order to avoid memory bias and stereotyping (see Areni, 2008), respondents were asked to log their current well-being and report their evening leisure activities just before going to bed on four consecutive weekday evenings. Evening leisure activities were defined as those performed after normal working hours that were unrelated to work. Respondents logged every activity and the time (in hours) spent performing them during the evening.

\subsection{Measures}

\subsubsection{Affective Well-Being}

Affective well-being reflects the frequent experience of positive affect, such as positive emotions and infrequent experience of negative affect, such as anxiety, fatigue and negative emotions (Diener \& Larsen, 1993). According to researchers in the field of psychological well-being (Daniels, 2000; Diener \& Larsen, 1993; Warr, 1990), measures of affective well-being are amongst the most important, if not the most important, indicators of psychological well-being. Thus, a scale of momentary (i.e., right now) affective well-being was created to assess a wide variety of momentary affective states to allow comprehensive measurement of affective states variation across four days. The 22 items from Warr's (1990) and Daniels et al. (1997) affective well-being scales, consisting of a series of single words describing positive emotions (e.g., "Cheerful"), negative emotions (e.g., "Miserable"), fatigue (e.g., "Tired"), and anxiety (e.g., "Anxious") were selected by the research team. At each time of measurement, participants were asked to rate the degree to which they experienced each specific feeling "right now". The response scale ranged from 1 (Not at all) to 6 (Very much). The principal component analysis and Cronbach's alphas are presented in the results section.

\subsubsection{Evening Leisure Activities}

Over four consecutive workdays, respondents were provided with an activity diary for each day containing a list of prototypical physical, social and low-effort activities (Sonnentag, 2001). Examples provided to the participants for physical activity were deliberate exercise, swimming, jogging, sports and yoga. The following examples were given for social activity: meeting with friends or family, speaking with friends on the phone and going out with one's partner. The latter were considered as good examples of social activity since they have a focus on social contacts and they provide opportunities for receiving social support. Examples offered for low-effort activity were watching television, reading a book, napping and taking a bath. These examples were given to participants in order to highlight that low-effort activity does not involve social contact and is both passive and sedentary in nature in comparison to physical or social activities. Over four consecutive evenings just before their usual nighttime routine, respondents recorded the amount of time spent on each activity category during that evening (i.e., after work until before sleep).

\subsection{Data Analyses}

\subsubsection{Principal Component Analysis}

In order to create coherent affect composite scores of well-being based on participants' responses, the 22 items from the Monday evening questionnaire were analyzed using a Principal Component Analysis (PCA). Oblimin rotation was used since several components of well-being were expected to be correlated (Meyers, Gamst, \& Guarino, 2006). 


\subsubsection{Correlation Analyses}

In order to assess the sign and strength of the relationships between sociodemographic variables, evening leisure activities, and outcome variables, correlation analyses were conducted. Pearson's correlation coefficients were used for interval data (i.e., age, number of children, years in organization, hours of work/week, evening leisure activities, and outcome variables), while Spearman's correlation coefficients were used for ordinal variables (i.e., gender and status).

\subsubsection{Hierarchical Linear Models}

In order to test hypotheses 1 to 3, a series of hierarchical linear models were constructed using HLM 7 (Raudenbush, Bryk, \& Congdon, 2011). Hierarchical linear models were used because the present study involved repeated measurements, nested within individuals. This type of analytical model is also the most common in diary studies, as it takes into consideration the shared variance due to multiple measurement occasions and controls for missing data at the group-level (Field, 2009; Reis \& Gable, 2000). When data are nested within participants, the standard errors generated from HLM are less biased than those from analysis of variance (ANOVA; Raudenbush \& Bryk, 2002). The final analysis sample consisted of 4 days nested within 95 persons (380 data points). The intraindividual variance (Level 1) is of primary interest here. Following standard procedures for separating person and days' associations (Ohly, Sonnentag, Niessen, \& Zapf, 2010) all predictors at Level 1 were centered to the group mean (within-level) so hypotheses could be tested. More precisely, the within-person level (Level 1) was used to estimate the influence of daily time spent on each type of leisure activity separately on each of the affective well-being components over the four days of the study. The control variable at Level 2 (i.e., age) was centered to the grand mean (between-level). The estimation method was restricted maximum likelihood (e.g., Trougakos, Hideg, Cheng, \& Beal, 2014). Hypotheses were tested in a two-tailed manner and the random effect of the intercept and slopes were inserted in the analyses. Each predicted variable (i.e., positive emotions, negative emotions, anxiety and fatigue) was analyzed separately using the following equations:

Level 1: Well-being ${ }_{i j}=\beta_{0 j}+\beta_{1 j}(\text { Duration of activities })_{i j}+r_{i j}$

Level 2: $\beta_{0 \mathrm{j}}=\mathrm{y}_{00}+\mathrm{y}_{01}($ Age $)+\mathrm{u}_{0 \mathrm{j}}$

\section{Results}

\subsection{Principal Component Analysis}

The Kaiser-Meyer-Olkin (KMO) value was .84, revealing a very good adequacy for PCA (Field, 2009). All KMO values for each item were above .78 which is above the limit of .50 (Field, 2009). Barlett's test of sphericity $\chi^{2}(120)$ $=5571.41, p<.001$ highlighted that the $R$-Matrix is not an identity matrix, and that correlation between items are sufficiently large for conducting a PCA. The cut-off point for factor loading was .30 (Leech, Barrett, \& Morgan, 2015). Four factors had eigenvalues over Kaiser's criterion of 1 , explaining a total of $72.72 \%$ of the variance. The scree plot revealed inflexions that justified retaining four factors. The four factors were: positive emotions $(9$ items), negative emotions ( 6 items), anxiety ( 3 items) and fatigue ( 4 items), which respectively account for $39.57 \%$, $18.23 \%, 9.25 \%$, and $5.64 \%$ of the variance. Cronbach's alphas were .82 for positive emotions, .91 for negative emotions, .87 for anxiety and .84 for fatigue at baseline (i.e., on Monday). Loadings are shown in Table 1 .

\subsection{Correlation Analyses}

Bivariate correlations are presented in Table 2 . Age was negatively correlated with daily negative emotions $(r=$ $-.25)$ and fatigue $(r=-.24)$. Therefore, age was used as a control variable in the fatigue and negative emotions models reported in Table 3. The other sociodemographic variables (i.e., gender, number of children, years in organization, status, and hours of work/week) were not correlated to any outcome variables. Thus, they were not controlled in the analyses.

\subsection{Hierarchical Linear Models}

\subsubsection{Leisure Physical Activity}

As summarized in Table 3, support was found for hypotheses 1a, $1 \mathrm{~b}$ and 1d, but not for hypothesis $1 \mathrm{c}$. Specifically, when participants spent more time performing physical activity during workday evenings than their own personal average, they reported more positive emotions $\left(\gamma_{10}=.14, p<.001\right)$, less negative emotions $\left(\gamma_{10}=-.06, p=.002\right)$ and less fatigue $\left(\gamma_{10}=-.13, p<.001\right)$. However, results suggest that time spent on physical activity did not contribute significantly to individual variations of anxiety across workdays $\left(\gamma_{10}=-.05, p=n\right.$. s. $)$. 
Table 1. Well-being item factor loadings (x 100): oblimin rotation

\begin{tabular}{|c|c|c|c|c|}
\hline Item & Positive emotions & Negative emotions & Anxiety & Fatigue \\
\hline \multicolumn{5}{|c|}{ Factor loadings } \\
\hline 1. Anxious & & & .76 & \\
\hline 2. Worried & & & .79 & \\
\hline 3. Tensed & & & .61 & \\
\hline 4. Cheerful & .84 & & & \\
\hline 5. Нарpy & .75 & & & \\
\hline 6. Pleased & .46 & & & \\
\hline 7. Miserable & & .77 & & \\
\hline 8. Gloomy & & .76 & & \\
\hline 9. Annoyed & & .59 & & \\
\hline 10. Dull & & .76 & & \\
\hline 11. Sluggish & & & & .46 \\
\hline 12. Bored & & .60 & & \\
\hline 13. Depressed & & .92 & & \\
\hline 14. Optimistic & .83 & & & \\
\hline 15. Enthusiastic & .84 & & & \\
\hline 16. Motivated & .81 & & & \\
\hline 17. Full of energy & .74 & & & \\
\hline 18. Alter & .75 & & & \\
\hline 19. Active & .85 & & & \\
\hline 20. Tired & & & & .81 \\
\hline 21. Fatigued & & & & .82 \\
\hline 22. Sleepy & & & & .88 \\
\hline \multicolumn{5}{|c|}{ Factor correlations } \\
\hline Factor 1 & - & & & \\
\hline Factor 2 & .21 & - & & \\
\hline Factor 3 & .32 & .18 & - & \\
\hline Factor 4 & .24 & .39 & .06 & - \\
\hline
\end{tabular}

Note. $n=95$. Only the highest factor loadings are presented.

\subsubsection{Leisure Social Activity}

Results revealed that when participants spent more time on social activity than their own personal average, they reported more positive emotions $\left(\gamma_{10}=.14, p<.001\right)$, less negative emotions $\left(\gamma_{10}=-.06, p=.009\right)$, and less anxiety $\left(\gamma_{10}=-.09, p=.007\right)$. Thus, hypotheses $2 \mathrm{a}, 2 \mathrm{~b}$ and $2 \mathrm{c}$ were supported, whereas hypothesis $2 \mathrm{~d}$ was not. Spending more leisure time than usual on social activity was unrelated to fatigue $\left(\gamma_{10}=-.04, p=.403\right)$ across the four days of the study (see Table 3). 
Table 2. Means, standard deviations, and zero-order correlations

\begin{tabular}{|c|c|c|c|c|c|c|c|c|c|c|c|c|c|c|}
\hline Variables & $M$ & $S D$ & 1 & 2 & 3 & 4 & 5 & 6 & 7 & 8 & 9 & 10 & 11 & 12 \\
\hline \multicolumn{15}{|l|}{ Socio-demographic variables } \\
\hline 1. Age & 34.48 & 11.37 & & & & & & & & & & & & \\
\hline 2. Gender & 1.66 & .48 & $.24 *$ & & & & & & & & & & & \\
\hline 3. Children & .48 & .94 & $.48^{* *}$ & .08 & & & & & & & & & & \\
\hline 4. Years in organization & 4.85 & 5.92 & $.53 * *$ & .19 & $.25^{*}$ & & & & & & & & & \\
\hline 5. Status & 1.28 & .45 & $.36 * *$ & .05 & $.23 *$ & $.23 *$ & & & & & & & & \\
\hline 6. Hours of work/week & 38.57 & 7.97 & $-.21^{*}$ & $-.34^{* *}$ & -.05 & -.07 & -.15 & & & & & & & \\
\hline \multicolumn{15}{|l|}{ Daily activities } \\
\hline 7. Daily physical duration & .32 & .40 & $-.21^{*}$ & $-.21^{*}$ & -.16 & -.18 & -.10 & .12 & & & & & & \\
\hline 8. Daily social duration & .97 & .77 & -.16 & -.05 & $-.27 * *$ & -.16 & -.12 & .02 & .12 & & & & & \\
\hline 9. Daily low effort duration & 1.63 & .87 & .06 & -.11 & -.04 & -.05 & -.17 & -.14 & -.02 & -.17 & & & & \\
\hline \multicolumn{15}{|l|}{ Daily well-being } \\
\hline 10. Daily positive emotions & 1.80 & .74 & .13 & .02 & .04 & .08 & .14 & .18 & $.22 *$ & .16 & -.17 & & & \\
\hline 11. Daily negative emotions & .30 & .39 & $-.25^{*}$ & -.12 & -.14 & -.16 & -.06 & .08 & -.07 & -.14 & .20 & $-.32 * *$ & & \\
\hline 12. Daily anxiety & .54 & .53 & -.07 & .08 & -.15 & -.08 & -.04 & .05 & -.19 & -.18 & .08 & $-.35 * *$ & $.61^{* *}$ & \\
\hline 13. Daily fatigue & 1.86 & .84 & $-.24 *$ & -.07 & -.08 & -.14 & -.01 & .01 & -.15 & -.18 & -.08 & $-.45 * *$ & $.47 * *$ & $.33 * *$ \\
\hline
\end{tabular}

Note. $\mathrm{n}=95$. Children: number of children. Years in organization: average tenure with the current institution. Gender: $1=$ Male, $2=$ Female. Status $=(1)$ employee, (2) director. Daily social, physical and low-effort duration = week mean duration of each type of activities per day (in hours). $*=$ significant at $\mathrm{p}<.05 ; * *=$ significant at $\mathrm{p}<.01$.

Table 3. Result from the HLM analyses on well-being according to the types of leisure time activities

\begin{tabular}{|c|c|c|c|c|c|c|c|c|c|c|c|c|}
\hline \multirow[b]{2}{*}{ Variable } & \multicolumn{3}{|c|}{ Daily positive emotions } & \multicolumn{3}{|c|}{ Daily negative emotions } & \multicolumn{3}{|c|}{ Daily anxiety } & \multicolumn{3}{|c|}{ Daily fatigue } \\
\hline & $\beta$ & $t$-ratio & $p$ & $\beta$ & $t$-ratio & $P$ & $\beta$ & $t$-ratio & $p$ & $\beta$ & $t$-ratio & $p$ \\
\hline \multicolumn{13}{|l|}{ Slopes as outcomes, $\beta_{i j}$} \\
\hline \multicolumn{13}{|l|}{ Control variable } \\
\hline Age $\left(\gamma_{11}\right)$ & & & & .00 & .02 & .986 & & & & .00 & -.34 & .734 \\
\hline \multicolumn{13}{|l|}{ Means as outcomes, $\beta_{0 \mathrm{j}}$} \\
\hline Intercept $\left(\gamma_{00}\right)$ & 1.79 & 25.33 & $<.001$ & .30 & 7.62 & $<.001$ & .54 & 10.15 & $<.001$ & 1.84 & 22.74 & $<.001$ \\
\hline Physical activity duration $\left(\gamma_{10}\right)$ & .14 & 4.52 & $<.001$ & -.06 & -3.18 & .002 & -.05 & -1.97 & .052 & -.13 & -3.90 & .001 \\
\hline \multicolumn{13}{|l|}{ Slopes as outcomes, $\beta_{i j}$} \\
\hline \multicolumn{13}{|l|}{ Control variable } \\
\hline Age $\left(\gamma_{11}\right)$ & & & & .00 & .59 & .560 & & & & .00 & .22 & .829 \\
\hline \multicolumn{13}{|l|}{ Means as outcomes, $\beta_{0 \mathrm{j}}$} \\
\hline Intercept $\left(\gamma_{0 \theta}\right)$ & 1.79 & 24.81 & $<.001$ & .29 & 7.48 & $<.001$ & .53 & 9.88 & $<.001$ & 1.85 & 22.41 & $<.001$ \\
\hline Social activity duration $\left(\gamma_{10}\right)$ & .14 & 3.42 & $<.001$ & -.06 & -2.65 & .009 & -.09 & -2.74 & .007 & -.04 & -.84 & .403 \\
\hline \multicolumn{13}{|l|}{ Slopes as outcomes, $\beta_{i j}$} \\
\hline \multicolumn{13}{|l|}{ Control variable } \\
\hline Age $\left(\gamma_{11}\right)$ & & & & .00 & -.99 & .323 & & & & .00 & -.23 & .821 \\
\hline \multicolumn{13}{|l|}{ Means as outcomes, $\beta_{0 j}$} \\
\hline Intercept $\left(\gamma_{00}\right)$ & 1.78 & 24.93 & $<.001$ & .26 & 7.68 & $<.001$ & -.54 & 9.70 & $<.001$ & 1.85 & 21.57 & $<.001$ \\
\hline Low-effort activity duration $\left(\gamma_{10}\right)$ & -.12 & -2.79 & .007 & .04 & 1.06 & .291 & .05 & 1.40 & .164 & .00 & .07 & .948 \\
\hline
\end{tabular}

Note. $n$ at Level $1=380 . n$ at Level $2=95$. Leisure activities duration is in hour. 


\subsubsection{Low-Effort Leisure Activity}

Hypotheses $3 \mathrm{a}, 3 \mathrm{~b}, 3 \mathrm{c}$ and $3 \mathrm{~d}$ were not supported. Contrary to expectations, spending more time on low-effort activity than usual was not associated with any change in self-reported negative emotions $\left(\gamma_{10}=.04, p=.291\right)$, anxiety $\left(\gamma_{10}=.05, p=.164\right)$ or fatigue $\left(\gamma_{10}=.00, p=.948\right)$. As can be seen in Table 3 , when participants spent more time on low-effort activity than their own personal average, they experienced less positive emotions before sleep $\left(\gamma_{10}=-.12, p=.007\right)$.

\section{Discussion}

This study adds to the current knowledge of the contribution of leisure to daily well-being (e.g., Snippe et al., 2016; Sonnentag, 2001) by adding further empirical support to workers' well-being literature, using a sample of office-based staff from the UK. Along with strengthening previous conclusions, the current study has the advantage to focus on the specific benefits from the three most common categories of evening leisure activities on affective well-being. The present study enlightens daytime workers in office work positions on the ways leisure activities could support their daily well-being. Indeed, results from the current study highlight the mood-enhancing potential of post-work physical and social leisure activities. Results also indicate that spending time on low-effort activity is perhaps not an adequate way to increase one's well-being as there was no relationship between time spent on this type of activity and negative emotions, fatigue and anxiety. Moreover, spending more time than usual on low-effort activity was associated with a decrease in positive emotions.

\subsection{Evening Leisure Activities and Daily Affective Well-Being}

\subsubsection{Physical Activity}

This study reinforces current knowledge by showing that physical activity has a positive influence on office-based staff's daily affective well-being. Spending more time than one's own personal average on physical activity during leisure time (i.e., after the workday) was associated with more positive and less negative emotions than usual. Being more physically active compared to one's personal average was also related to decreases in daily fatigue, even though activities such as exercise or sport may be physically strenuous. However, time spent on physical activity did not significantly predict daily anxiety, but the $p$ value $(p=.052)$ suggested that this relationship may be significant within a larger sample with more daily observations.

A number of mechanisms have been identified to explain the benefits of physical activity on daily emotions and fatigue. For instance, these physiological mechanisms have been highlighted: (1) increased levels of endorphins (Dishman \& O'Connor, 2009), (2) increased levels of noradrenaline, serotonin, and dopamine, which act as antidepressants (Rimmele et al., 2009), and (3) the elevation of body temperature (i.e., the thermogenic hypothesis; Raglin \& Morgan, 1985).

The benefits of physical activity may also be derived from various psychological mechanisms. First, physical activity may enhance the ability to cope with stress (Yang et al., 2010), thus increasing affective well-being on a daily basis. Physical activity may generate or replenish valued personal resources, such as a sense of self-worth or renewed energy (Hobföll, 1989). It can also provide distraction from work-related problems or daily strain (Toker \& Biron, 2012). By attending to their body or surrounding environment during physical activity, participants potentially diverted their attention from repetitive cognitive content, such as worry and rumination about work, which can be detrimental to affective well-being (Flaxman, Menard, Kinman, \& Bond, 2012). Physical activity may also cultivate a state of flow in which the person is fully absorbed in the current task or experience (e.g., Elbe, Barene, Strahler, Krustrup, \& Holtermann, 2016). This could in turn prevent people from ruminating on lingering issues from the workday and facilitate healthy psychological detachment from work (Sonnentag, 2001; Sonnentag \& Fritz, 2007).

In this study, physical activity was the only leisure activity category linked to less fatigue across the workweek. This result is in line with previous studies that have shown that regular physical activities are related to a reduction of fatigue (Åkerstedt et al., 2004; Berlin, Kop, \& Deuster, 2006; Ohta, Okufuji, Matsushima, \& Ikeda, 2004). Miller (2006) stated that physical activity may help to reduce fatigue by increasing physical fitness, metabolic rate and endurance, thereby reducing the strain of undertaking everyday responsibilities. So, even if going to the gym, engaging in sports or being active requires more effort, this study highlighted that engaging in such activities on a daily basis has good potential for reducing post-work fatigue of office-based employees.

\subsubsection{Social Activity}

As expected in a sample of office-based staff that need cognitive and emotional resources to meet work demands, spending more time than usual on social activity after work was associated with decreased anxiety and negative emotions as well as enhanced positive emotions before sleep. This replicates results from studies that showed a 
positive relationship between social activity and positive mood (e.g., Lee \& Szinovacz, 2016; Vittengl \& Holt, 1998; Watson, Clark, McIntyre, \& Hamaker, 1992).

As it was the case for physical activity, the observed benefits of engaging in social activity could also be explained by its potential for resource replenishment (Hobföll, 1989). According to Hobföll (1989), close relationships with friends or involvement with other people who share the same interests are likely to be valued social resources, and investing in them may be one route to affective well-being. First, social activity may provide opportunities for emotional and/or instrumental social support (Cohen \& Wills, 1985), a resource. Second, devoting more time than usual in social activity is likely to contribute to fulfilling one's basic psychological needs, again leading to well-being. According to a study by Ryan et al. (2010), the workweek provides fewer opportunities for satisfying one's need for relatedness since workers have fewer occasions to meet with friends, and tend to engage in more solitary forms of leisure activities. Thus, social activity could also support one's need for relatedness and consequently lead to well-being. Since office-based staff mainly spends cognitive and emotional resources at work, social activity could be a particularly good opportunity to build a new capital of both social and emotional resources, thus fostering daily well-being.

\subsubsection{Low-Effort Activity}

Low-effort activity had no influence on daily well-being of office-based staff except for positive emotions before sleep, that were lower on days when more time than usual was devoted to this type of activity after the workday. Thus, not only was devoting time to this type of leisure activity not beneficial on a daily basis, it was also associated with a psychological cost. There are two possible explanations for such results. On the absence of effect, low-effort leisure includes below-baseline activities that do not call upon one's existing personal resources or help build new ones (Sonnentag, 2001). This could explain why reported anxiety, fatigue and negative emotions were comparable to the baseline (i.e., one's own personal average). Concerning the decrease in positive emotions, since time for leisure is limited because of other life roles such as work and childcare, allocating it to low-effort activity inevitably means less participation in other types of evening activities. Those other leisure activities (such as physical or social activities) may lead to the replenishment of resources and ultimately, psychological health and well-being (Motl, McAuley, Birnbaum, \& Lytle, 2006). Thus, devoting time to low-effort activity is less likely to improve daily well-being.

Moreover, according to Iso-Ahola and Haworth (1997), passive leisure activity may have detrimental effects because they may not elicit joy, happiness or enthusiasm (i.e., positive emotions), and instead result in boredom and a feeling of apathy (Rook \& Zijlstra, 2006). Furthermore, since such activities do not involve seeking achievement and rewards, they may be less resourceful and beneficial to daily well-being than more active forms of leisure. Furthermore, Sonnentag (2001) stated that engaging in low-effort activity could be a consequence of a stressful work context or poor health. Therefore, a correlation between low-effort activity and decreased positive affect could be explained by other variables related to one's work (e.g., heavy workload, low control) or health (e.g., depression). Indeed, depressed individuals have a tendency to engage more in low-effort (i.e., passive) leisure activity (Wells et al., 1989). Nevertheless, as indicated earlier, low-effort evening activity may be most common among working age adults, and are perceived as replenishing. However, the results of this and other studies (e.g., Rook \& Zijlstra, 2006; Sonnentag \& Zijlstra, 2006) indicate that this may be a misconception. To promote daily affective well-being, daily leisure time should be devoted to activities that are physical or social in nature rather than just passive, with no social contact.

\subsection{Strengths, Limitations and Future Research}

The present study used a daily survey design over four consecutive weekday evenings (Monday to Thursday), capturing individual variations in time spent on evening activities and daily well-being of a sample of office-based workers. This approach has advantages over others that rely on participants' retrospective reports of typical leisure time use (MacFarlane, Martin, \& Williams, 1988). To our knowledge, this is one of only a handful of studies (e.g., Demerouti et al., 2009; Sonnentag, 2001) to have established specific and differential relationships between affective well-being variation at the within-person level and amount of physical, social and low-effort activities performed during the workweek. Understanding the manner in which each of the most common types of evening leisure activity contributes to daily well-being may help to determine how workers can contribute to their own psychological health through leisure.

Along with the strengths identified above, this study also has some limitations. First, the sample size was small (N $=95$ ) which limits generalization. However, Ohly et al. (2010) consider a sample size of more than 30 participants is sufficient and since measures were administered several times the external validity is reinforced. 
Second, the day-level survey design does not allow establishing causality. Based on theory and previous research, this work was based on the assumption that certain activities have mood-enhancing effects. Nevertheless, it could be argued that individuals experiencing well-being during the evening are more likely to engage in social or physical activities and those feeling less positive may be more inclined to conduct low-effort activity. However, the behaviour-consequence temporal sequencing was respected. Thus, participants in this study reported well-being before sleep after having performed the activities in the evening.

Third, the sample of office-based staff was drawn from diverse industrial sectors. Different jobs from various sectors imply various amounts and kinds of social interaction (see Argyle, 1973 for a review). Although office-based staff allowed considering a comprehensive sample of jobs, a more homogenous sample would allow comparing jobs that have even more similar resources and demands.

Fourth, it is also worth noting that most participants in this study did not have children. Since having children means allocating more time to childcare activity, it may have reduced opportunities to spend time on physical and social activities. Future research on leisure time should thus try to include parents.

Fifth, this study did not address the influence of health and clinical status of workers on the benefits of leisure activities. In future studies, it would be useful to examine if workers with particular characteristics benefit more from one or other types of leisure category. For instance, workers with neuroticism or social anxiety might enjoy and benefit more from physical rather than social activities in order to increase their well-being. Moreover, relatively little is known about the personality characteristics or coping styles that could influence the choice and function of leisure activity (Flaxman et al., 2012). Such variables were not included in this study, but it seems reasonable to assume that individual characteristics (e.g., the big five traits) would also have an influence on individuals' leisure choices and investigation outcomes (Ajzen \& Driver, 1992; Melamed \& Meir, 1981).

Finally, given that this study relied exclusively on self-reported data, alternative data collection approaches should also be considered, for example, spousal ratings (Sonnentag, Kuttler, \& Fritz, 2010) and physiological indices of well-being (Cropley et al., 2006). Such alternative data collection could also take into consideration the specific nature of the activities that individuals perform after work in order to examine if every type of physical, social and low-effort activities has the same impact on their well-being. For instance, is talking to someone on the phone as beneficial as going out with friends? Such precisions should be looked at in future studies on leisure activities and well-being of workers.

\subsection{Implications and Conclusion}

Results from this study of office-based staff suggest that individuals may benefit from spending time on physical and social activities on a daily basis. For those who feel fatigued, it may not be easy to muster the enthusiasm for physical activity after a busy workday. Nonetheless, data from this study suggest this may be a wise behavioural choice, at least on some days of the week. It can be going to the gym, as well as going for a walk. Social activity significantly contributed to enhanced well-being as well. Thus, being active and seeing friends could be an easy and accessible way to promote one's affective well-being on a daily basis. Likewise, although low-effort activity may seem to be the sensible (and certainly the easiest) option, they may offer relatively little in terms of resource replenishment. Such passive activity may even result in less positive emotional opportunities.

In order to fully benefit from the positive consequences of leisure activity, workers should make informed choices regarding leisure. Since time available for leisure is limited and can support daily affective well-being, workers should try to choose leisure activities that fulfill multiple psychological needs. For instance, workers could choose to devote more time to playing sports with friends, since this kind of activity fulfills their need for relatedness as well as their need for psychological detachment from work. In the same vein, devoting time to watching television after work should be an activity that workers try to reduce, since it only fulfills one psychological need at a time (i.e., psychological relaxation; Newman, Tay, \& Diener, 2014).

Well-being is recognized as a predictor of performance at work (Robertson, Jansen Birch, \& Cooper, 2012). It is therefore imperative that organizations pay particular attention to it. Given that this study highlighted that physical and social activities contribute to daily affective well-being, organizations should not only try to adapt working conditions (e.g., workload, work schedule) in order to promote organizational health: they should also dwell on the challenges that workers face outside of the work environment (Rook \& Zijlstra, 2006). For example, organizations could reduce the permeability of the frontiers between the work and home domains by reducing the work-related communications outside of regular business hours. By doing so, they will ensure that workers will have the opportunity to devote their time to leisure activities that have the potential to increase their daily well-being (Park, Fritz, \& Jex, 2011). 


\section{References}

Åkerstedt, T., Knutsson, A., Westerholm, P., Theorell, T., Alfredsson, L., \& Kecklund, G. (2004). Mental fatigue, work and sleep. Journal of Psychosomatic Research, 57(5), 427-433. http://dx.doi.org/10.1016/j.jpsychores.2003.12.001

Areni, C. S. (2008). (Tell me why) I don't like Mondays: Does an overvaluation of future discretionary time underlie reported weekly mood cycles? Cognition and Emotion, 22(7), 1228-1252. http://dx.doi.org/10.1080/02699930701686107

Argyle, M. (1973). Social interaction. London, U.K.: Aldine Transaction.

Ajzen, I., \& Driver, B. L. (1992). Application of the theory of planned behavior to leisure choice. Journal of Leisure Research, 24(3), 207-224.

Berlin, A. A., Kop, W. J., \& Deuster, P. A. (2006). Depressive mood symptoms and fatigue after exercise withdrawal: The potential role of decreased fitness. Psychosomatic Medicine, 68(2), 224-230. http://dx.doi.org/10.1097/01.psy.0000204628.73273.23

Brannan, D., Biswas-Diener, R., Mohr, C. D., Mortazavi, S., \& Stein, N. (2013). Friends and family: A cross-cultural investigation of social support and subjective well-being among college students. The Journal of Positive Psychology, 8(1), 65-75. http://dx.doi.org/10.1080/17439760.2012.743573

Bucksch, J., \& Schlicht, W. (2006). Health-enhancing physical activity and the prevention of chronic diseases-An epidemiological review. Sozial-und Präventivmedizin SPM, 51(5), 281-301. http://dx.doi.org/10.1007/s00038-006-5043-4

Bültmann, U., Kant, I., Kasl, S. V., Schroer, K. A. P., Swaen, G. M. H., \& van den Brandt, P. A. (2002). Lifestyle factors as risk factors for fatigue and psychological distress in the working population: Prospective results from the Maastricht Cohort Study. Journal of Occupational and Environmental Medicine, 44(2), 116-124. http://dx.doi.org/10.1097/00043764-200202000-00006

Bureau of Labor Statistics. (2016). Employment experience of youth: Results from a longitudinal survey news release. Retrieved from http://www.bls.gov/news.release/nlsyth.toc.htm

Brajša-Žganec, A., Merkaš, M., \& Šverko, I. (2011). Quality of life and leisure activities: How do leisure activities contribute to subjective well-being? Social Indicators Research, 102(1), 81-91. http://dx.doi.org/10.1007/s11205-010-9724-2

Caspersen, C. J., Powell, K. E., \& Christenson, G. M. (1985). Physical activity, exercise, and physical fitness: Definitions and distinctions for health-related research. Public Health Reports, 100(2), 126-131.

Celen-Demirtas, S., Konstam, V., \& Tomek, S. (2015). Leisure activities in unemployed emerging adults: Links to career adaptability and subjective well-being. The Career Development Quarterly, 63(3), 209-222. http://dx.doi.org/10.1002/cdq.12014

Chang, P. J., Wray, L., \& Lin, Y. (2014). Social relationships, leisure activity, and health in older adults. Health Psychology, 33(6), 516-523. http://dx.doi.org/10.1037/hea0000051

Chesley, N. (2014). Information and communication technology use, work intensification and employee strain and distress. Work, Employment \& Society, 28(4), 589-610. http://dx.doi.org/10.1177/0950017013500112

Clark, L. A., \& Watson, D. (1988). Mood and the mundane: Relations between daily life events and self-reported mood. Journal of Personality and Social Psychology, 54(2), 296-308. http://dx.doi.org/10.1037/0022-3514.54.2.296

Coffeng, J. K., van Sluijs, E. M., Hendriksen, I. J. M., van Mechelen, W., \& Boot, C. R. L. (2015). Physical activity and relaxation during and after work are independently associated with the need for recovery. Journal of Physical Activity \& Health, 12(1), 109-115. http://dx.doi.org/10.1123/jpah.2012-0452

Cohen, S., \& Wills, T. A. (1985). Stress, social support, and the buffering hypothesis. Psychological Bulletin, 98(2), 310-357. http://dx.doi.org/10.1037/0033-2909.98.2.310

Cropley, M., Dijk, D. K., \& Stanley, N. (2006). Job strain, work rumination, and sleep in school teachers. European Journal of Work and Organizational Psychology, 15(2), 181-196. http://dx.doi.org/10.1080/13594320500513913

Daniels, K. (2000). Measures of five aspects of affective well-being at work. Human Relations, 53(2), 275-294. http://dx.doi.org/10.1177/0018726700532005 
Daniels, K., Brough, P., Guppy, A., Peters-Bean, K. M., \& Weatherstone, L. (1997). A note on modification to Warr's measures of affective well-being at work. Journal of Occupational and Organizational Psychology, 70(2), 129-138. http://dx.doi.org/10.1111/j.2044-8325.1997.tb00638.x

Deci, E. L., \& Ryan, R. M. (2000). The "what" and "why" of goal pursuits: Human needs and the self-determination of behavior. Psychological Inquiry: An International Journal for the Advancement of Psychological Theory, 11(4), 227-268. http://dx.doi.org/10.1207/S1-5327965PLI1104_01

de Jonge, J., \& Dormann, C. (2006). Stressors, resources, and strain at work: A longitudinal test of the triple-match principle. Journal of Applied Psychology, 91(6), 1359-1374. http://dx.doi.org/10.1037/0021-9010.91.5.1359

de Jong, T., Wiezer, N., de Weerd, M., Nielsen, K., Mattila-Holappa, P., \& Mockałło, Z. (2016). The impact of restructuring on employee well-being: A systematic review of longitudinal studies. Work \& Stress, 30(1), 91-114. http://dx.doi.org/10.1080/02678373.2015.1136710

Demerouti, E., Bakker, A. B., Geurts, S. A. E., \& Taris, T. W. (2009). Daily recovery from work-related effort during non-work time. In S. Sonnentag, P. L. Perrewe, \& D. C. Ganster (Eds.), Research in occupational stress and well being: Current perspectives on job-stress recovery (Vol. 7, pp. 85-123). London, U.K.: JAI Press.

Diener, E., \& Larsen, R. J. (1993). The experience of emotional well-being (J. M. Haviland (Ed.)). New York, NY.: Guildford Press.

Dishman, R. K., \& O'Connor, P. J. (2009). Lessons in exercise neurobiology: The case of endorphins. Mental Health \& Physical Activity, 2(1), 4-9. http://dx.doi.org/10.1016/j.mhpa.2009.01.002

Doerksen, S. E., Elavsky, S., Rebar, A. L., \& Conroy, D. E. (2014). Weekly fluctuations in college student leisure activities and well-Being. Leisure Sciences, 36(1), 14-34. http://dx.doi.org/10.1080/01490400.2014.860778

Eden, D. (2001). Vacations and other respites: Studying stress on and off the job. In C. L. Cooper, \& I. T. Robertson (Eds.), International review of industrial and organizational psychology (pp. 121-146). Chichester: Wiley.

Elbe, A. M., Barene, S., Strahler, K., Krustrup, P., \& Holtermann, A. (2016). Experiencing flow in a workplace physical activity intervention for female health care workers: A longitudinal comparison between football and zumba. Women in Sport and Physical Activity, 24(1), 70-77. http://dx.doi.org/10.1123/wspaj.2015-0011

Field, A. (2009). Discovering statistics using SPSS. London, U.K.: Sage publications.

Flaxman, P. E., Ménard, J., Kinman, G., \& Bond, F. (2012). Academics' experiences of a respite from work: Effects of self-critical perfectionism and perseverative cognition on postrespite well-being. Journal of Applied Psychology, 97(4), 854-865. http://dx.doi.org/10.1037/a0028055

Fritz, C., \& Sonnentag, S. (2005). Recovery, health, and job performance: Effects of weekend experiences. Journal of Occupational Health Psychology, 10(3), 187-199. http://dx.doi.org/10.1037/1076-8998.10.3.187

Greenhaus, J. H., \& Powell, G. N. (2006). When work and family are allies: A theory of work-family enrichment. Academy of Management Review, 31(1), 72-92. http://dx.doi.org/10.5465/AMR.2006.19379625

Hobföll, S. E. (1989). Conservation of resources: A new attempt at conceptualizing stress. American Psychologist, 44(3), 513-524. http://dx.doi.org/10.1037/0003-066X.44.3.513

Hobföll, S. E. (2002). Social and psychological resources and adaptation. Review of General Psychology, 6(4), 307. http://dx.doi.org/10.1037/1089-2680.6.4.307

Hobföll, S. E., \& Shirom, A. (1993). Stress and burnout in the workplace: Conservation of resources. In T. Golombiewski (Ed.), Handbook of organizational behavior (pp. 41-61). New York: Marcel Dekker.

Hyde, A. L., Conroy, D. E., Pincus, A. L., \& Ram, N. (2011). Unpacking the feel good effect of free-time physical activity: Between-and within-person associations with pleasant-activated feeling states. Journal of Sport \& Exercise Psychology, 33(6), 884-902. http://dx.doi.org/10.1123/jsep.33.6.884

Industry Classification Benchmark. (2010). ICB database. Retrieved from http://www.icbenchmark.com/ICBDocs/Structure_Defs_English.pdf

International Labour Organization. (2008). ILOSTAT database. Retrieved from http://www.ilo.org/global/statistics-and-databases/lang--en/index.htm

Iso-Ahola, S. E. (1980). The social psychology of leisure and recreation. Dubuque, IA: William C. Brown. 
Iso-Ahola, S. E., \& Haworth, J. T. (1997). Work, Leisure \& Well-Being (M. Strang (Ed.)). Taylor \& Francis Group/Books.

Iwasaki, Y. (2001). Contributions of leisure to coping with daily hassles in university students' lives. Canadian Journal of Behavioural Science, 33(2), 128-141. http://dx.doi.org/10.1037/h0087135

Kinnunen, U., Rantanen, J., de Bloom, J., Mauno, S., Feldt, T., \& Korpela, K. (2015). The role of work-nonwork boundary management in work stress recovery. International Journal of Stress Management, 23(2), 99-123. http://dx.doi.org/10.1037/a0039730

Korpela, K., \& Kinnunen, U. (2010). How is leisure time interacting with nature related to the need for recovery from work demands? Testing multiple mediators. Leisure Sciences, 33(1), 1-14. http://dx.doi.org/10.1080/01490400.2011.533103

Lee, H. J., \& Szinovacz, M. E. (2016). Positive, negative, and ambivalent interactions with family and friends: Associations with well-being. Journal of Marriage and Family, 78(3), 660-679. http://dx.doi.org/10.1111/jomf.12302

Leech, N. L., Barrett, K. C., \& Morgan, G. A. (2015). IBM SPSS for intermediate statistics: Use and interpretation. New-York: Routledge.

Lin, Y. S., Huang, W. S., Yang, C. T., \& Chiang, M. J. (2014). Work-leisure conflict and its associations with well-being: The roles of social support, leisure participation and job burnout. Tourism Management, 45, 244-252. http://dx.doi.org/10.1016/j.tourman.20-14.04.004

MacFarlane, J., Martin, C. L., \& Williams, T. M. (1988). Mood fluctuations. Psychology of Women Quarterly, 12(2), 201-223. http://dx.doi.org/10.1111/j.1471-6402.1988.tb00937.x

McMahon, E. M., Corcoran, P., O’Regan, G., Keeley, H., Cannon, M., Carli, V., ... Balazs, J. (2016). Physical activity in European adolescents and associations with anxiety, depression and well-being. European Child \& Adolescent Psychiatry, 1-12. http://dx.doi.org/10.1007/s00787-016-0875-9

Melamed, S., \& Meir, E. I. (1981). The relationship between interests-job incongruity and selection of avocational activity. Journal of Vocational Behavior, 18(3), 310-325. http://dx.doi.org/10.1016/0001-8791(81)90018-X

Meyers, L. S., Gamst, G., \& Guarino, A. (2006). Applied multivariate research: Design and interpretation. Thousand Oaks, CA: SAGE Publications.

Miller, R. G. (2006). Fatigue and therapeutic exercise. Journal of the Neurological Sciences, 242(1), 37-41. http://dx.doi.org/10.1016/j.jns.2005.11.012

Motl, R. W., McAuley, E., Birnbaum, A. S., \& Lytle, L. A. (2006). Naturally occurring changes in time spent watching television are inversely related to frequency of physical activity during early adolescence. Journal of Adolescence, 29(1), 19-32. http://dx.doi.org/10.1016/j.adolescence.2005.01.005

Newman, D. B., Tay, L., \& Diener, E. (2014). Leisure and subjective well-being: A model of psychological mechanisms as mediating factors. Journal of Happiness Studies, 15(3), 555-578. http://dx.doi.org/10.1007/s10902-013-9435-x

Nielsen Media Research. (2009). Three screen report: Television, Internet and mobile usage in the U.S. Retrieved from http://www.nielsonmedia.ca

Office for National Statistics. (2016). JOBS01: Workforce jobs summary. Retrieved from http://www.ons.gov.uk/employmentandlabourmarket/peopleinwork/employmentandemployeetypes/datasets /workforcejobssummaryjobs01

Ohly, S., Sonnentag, S., Niessen, C., \& Zapf, D. (2010). Diary studies in organizational research: An introduction and some practical recommendations. Journal of Personnel Psychology, 9(2), 79-93. http://dx.doi.org/10.1027/1866-5888/a000009

Ohta, M., Okufuji, T., Matsushima, Y., \& Ikeda, M. (2004). The effect of lifestyle modification on physical fitness and work ability in different workstyles. Journal of UOEH, 26(4), 411-421.

Paggi, M. E., Jopp, D., \& Hertzog, C. (2016). The importance of leisure activities in the relationship between physical health and well-being in a life span sample. Gerontology, 62(4), 450-458. http://dx.doi.org/10.1159/000444415 
Park, Y., Fritz, C., \& Jex, S. M. (2011). Relationships between work-home segmentation and psychological detachment from work: The role of communication technology use at home. Journal of Occupational Health Psychology, 16(4), 457-467. http://dx.doi.org/10.1037/a0023594

Raglin, J. S., \& Morgan, W. P. (1985). Influence of vigorous exercise on mood state. The Behavior Therapist, 8(9), 179-183.

Raglin, J. S., Wilson, G. S., \& Galper, D. (2007). Exercise and its effects on mental health. Physical Activity and Health, 1, 247-257.

Raudenbush, S. W., \& Bryk, A. S. (2002). Hierarchical linear models (2nd ed.). Thousand Oaks, CA: Sage.

Raudenbush, S. W., Bryk, A. S, \& Congdon, R. (2011). HLM 7 for Windows [Computer software]. Lincolnwood, IL: Scientific Software International, Inc.

Reed, J., \& Ones, D. S. (2006). The effect of acute aerobic exercise on positive activated affect: A meta-analysis. Psychology of Sport and Exercise, 7(5), 477-514. http://dx.doi.org/10.1016/j.psychsport.2005.11.003

Reis, H. T., \& Gable, S. (2000). Event-sampling and other methods for studying everyday experience. In H. T. Reis, \& C. M. Judd (dir.), Handbook of research methods in social and personality psychology (pp. 190-222). London, U.K.: Cambridge university press.

Rimmele, U., Seiler, R., Marti, B., Wirtz, P. H., Ehlert, U., \& Heinrichs, M. (2009). The level of physical activity affects adrenal and cardiovascular reactivity to psychosocial stress. Psychoneuroendocrinology, 34(2), 190-198. http://dx.doi.org/10.1016/j.psyneuen.20-08.08.023

Robertson, I. T., Jansen Birch, A., \& Cooper, C. L. (2012). Job and work attitudes, engagement and employee performance: Where does psychological well-being fit in? Leadership \& Organization Development Journal, 33(3), 224-232. http://dx.doi.org/10.1108/01437731211216443

Rook, J. W., \& Zijlstra, F. R. H. (2006). The contribution of various types of activities to recovery. European Journal of Work and Organizational Psychology, 15(2), 218-240. http://dx.doi.org/10.1080/13594320500513962

Ryan, R. M., Bernstein, J. H., \& Brown, K. W. (2010). Weekends, work, and well-being: Psychological need satisfactions and day of the week effects on mood, vitality, and physical symptoms. Journal of Social and Clinical Psychology, 29(1), 95-122. http://dx.doi.org/10.1521/jscp.2010.29.1.95

Saxbe, D. E., Graesch, A. P., \& Alvik, M. (2011). Television as a social or solo activity: Understanding families' everyday television viewing patterns. Communication Research Reports, 28(2), 180-189. http://dx.doi.org/10.1080/08824096.2011.566104

Schüz, B., Czerniawski, A., Davie, N., Miller, L., Quinn, M. G., King, C., ... Scott, J. L. (2015). Leisure time activities and mental health in informal dementia caregivers. Applied Psychology: Health and Well-Being, 7(2), 230-248. http://dx.doi.org/10.1111/aphw.12046

Sedentary Behaviour Research Network. (2012). Standardized use of the terms "sedentary" and "sedentary behaviours". Applied Physiology Nutrition and Metabolism, 37, 540-542. http://dx.doi.org/10.1139/h2012-024

Shaw, S. M. (1985). The meaning of leisure in everyday life. Leisure Sciences, 7(1), 1-24. http://dx.doi.org/10.1080/01490408509512105

Snippe, E., Simons, C. J., Hartmann, J. A., Menne-Lothmann, C., Kramer, I., Booij, S. H., ... Wichers, M. (2015). Change in daily life behaviors and depression: Within-person and between-person associations. Health Psychology, 35(5), 433-441. http://dx.doi.org/10.1037/hea0000312

Sonnentag, S. (2001). Work, recovery activities, and individual well-being: A diary study. Journal of Occupational Health Psychology, 6(3), 196-210. http://dx.doi.org/10.1037/1076-8998.6.3.196

Sonnentag, S., \& Bayer, U. V. (2005). Switching off mentally: Predictors and consequences of psychological detachment from work during off-job time. Journal of Occupational Health Psychology, 10(4), 393-414. http://dx.doi.org/10.1037/1076-8998.10.4.393

Sonnentag, S., Binnewies, C., \& Mojza, E. J. (2008). Did you have a nice evening? A day-level study on recovery experiences, sleep, and affect. Journal of Applied Psychology, 93(3), 674. 
Sonnentag, S., \& Fritz, C. (2007). The Recovery Experience Questionnaire: Development and validation of a measure for assessing recuperation and unwinding from work. Journal of Occupational Health Psychology, 12(3), 204-221. http://dx.doi.org/10.1037/1076-8998.12.3.204

Sonnentag, S., Kuttler, I., \& Fritz, C. (2010). Job stressors, emotional exhaustion, and need for recovery: A multi-source study on the benefits of psychological detachment. Journal of Vocational Behavior, 76(3), 355-365. http://dx.doi.org/10.1016/j.jvb.2009.06.005

Sonnentag, S., \& Natter, E. (2004). Flight attendants' daily recovery from work: Is there no place like home? International Journal of Stress Management, 11(4), 366. http://dx.doi.org/10.1037/1072-5245.11.4.366

Sonnentag, S., \& Zijlstra, F. R. H. (2006). Job characteristics and off-job activities as predictors of need for recovery, well-being, and fatigue. Journal of Applied Psychology, 91(2), 330-350. http://dx.doi.org/10.1037/0021-9010.91.2.330

Stebbins, R. A. (2005). Choice and experiential definitions of leisure. Leisure Sciences, 27(4), 349-352. http://dx.doi.org/10.1080/01490400590962470

Toker, S., \& Biron, M. (2012). Job burnout and depression: Unraveling their temporal relationship and considering the role of physical activity. Journal of Applied Psychology, 97(3), 699. http://dx.doi.org/10.1037/a0026914

Trougakos, J., Hideg, I., Cheng, B., \& Beal, D. (2013). Lunch breaks unpacked: The role of autonomy as a moderator of recovery during lunch. Academy of Management Journal, 57(2), 405-421. http://dx.doi.org/10.5465/amj.2011.1072

Vittengl, J. R., \& Holt, C. S. (1998). A time-series diary study of mood and social interaction. Motivation and Emotion, 22(3), 255-275. http://dx.doi.org/10.1023/A:1022388123550

Yang, X., Telama, R., Hirvensalo, M., Hintsanen, M., Hintsa, T., Pulkki-Raback, L., \& Vilkari, J. S. (2010). The benefits of sustained leisure-time physical activity on job strain. Occupational Medicine, 60(5), 369-375. http://dx.doi.org/10.1093/occmed/kqq019

Warr, P. (1990). The measurement of well-being and other aspects of mental health. Journal of Occupational Health Psychology, 63(3), 193-210. http://dx.doi.org/10.1111/j.2044-8325.1990.tb00521.x

Watson, D., Clark, L. A., McIntyre, C. W., \& Hamaker, S. (1992). Affect, personality, and social activity. Journal of Personality and Social Psychology, 63(6), 1011-1025. http://dx.doi.org/10.1037/0022-3514.63.6.1011

Wells, K. B., Stewart, A., Hays, R. D., Burnam, M. A., Rogers, W., Daniels, M., ... Ware, J. (1989). The functioning and well-being of depressed patients: Results from the Medical Outcomes Study. Jama, 262(7), 914-919. http://dx.doi.org/10.1001/jama.1989.03430070062031

Wipfli, B. M., Rethorst, C. D., \& Landers, D. M. (2008). The anxiolytic effects of exercise: A meta-analysis of randomized trials and dose-response analysis. Journal of Sport \& Exercise Psychology, 30(4), 392-410. http://dx.doi.org/10.1123/jsep.30.4.392

Wright, T. A., \& Hobföll, S. E. (2004). Commitment, psychological well-being and job performance: An examination of conservation of resources (COR) theory and job burnout. Journal of Business and Management, 9(4), 389-406. http://dx.doi.org/10.1177/0149206306297582

\section{Copyrights}

Copyright for this article is retained by the author(s), with first publication rights granted to the journal.

This is an open-access article distributed under the terms and conditions of the Creative Commons Attribution license (http://creativecommons.org/licenses/by/4.0/). 